\title{
PENGEMBANGAN BUDAYA ORGANISASI DENGAN ORGANIZATIONAL CULTURE ASSESSMENT INSTRUMENT DI PT XYZ
}

\author{
Ryyld Ipbtas Yusri \\ Program Studi S2 MM Eksekutif Muda \\ Sekolah Tinggi Manajemen PPM
}

In the year 1998-2010, PT XYZ have faced a tough business challenges. Therefore PT XYZ have establish a new strategic direction to ensure sustainable growth in long term period. Either one of that strategic is to develop high performance culture as enabler to achieve it's vision in 2020. However currently, PT XYZ have not had a comprehensive design how to develop organization culture. So the porpuse of this studi to describe the dominant culture type in both current and preferred situation as weel as by good right culture type which is aligned with the executives talent in PT XYZ. This study based on the Organizational Culture Assessment Instrument (OCAI) built upon a theoretical model called the "Competing Values Framework". This framework refers to whether an organization has predominant internal or external focus and whether it strives for flexibility or stability. Moreover, the purpose of the OCAI is to assess six key dimensions of organization culture. The results of this study showed that current organization culture is Hierarchy which is driven by efficiency, consistency and uniformity values. However, the preferred or the should be organization culture is Market which is driven by goal achievement and competitiveness values. Fortunately, the PT XYZ's executive talent have align with preferred culture so that it can ease to develop new organization culture. Several initiatives can be purposed to manage the change of the corporate culture. The initiatives consist of leadership role alignment, consistent communication, improve employees capability and optimize systems and procedures.

Keywords:

Organization culture, Organizationa Culture Assesment Instrument (OCAI), talent. 


\section{PENDAHULUAN}

\subsection{Latar Belakang Masalah}

Apa yang membedakan perusahaan yang benar-benar sukses dalam jangka panjang dengan perusahaan yang biasa-biasa saja? Cameron dan Kim (2006) menyatakan bahwa perusahaan-perusahaan yang sukses dalam jangka panjang tidak hanya ditentukan oleh hal-hal yang bersifat berwujud dan nyata. Namun hal tersebut lebih ditentukan oleh hal yang lebih bersifat intangible. Faktor intangible yang paling utama ini adalah budaya organisasi. Hal ini dianggap relevan karena memang budaya organisasi berhubungan langsung dan mempunyai dampak yang signifikan terhadap kinerja keuangan jangka panjang (Kotter dan Heskert, 1992).

PT XYZ Tbk (XYZ) sebagai salah satu perusahaan BUMN mengalami tantangan bisnis yang berat saat ini. Penurunan harga komoditas, peningkatan biaya operasional serta gagalnya eksekusi proyek-proyek strategis mengakibatkan menurunnya keuntungan perusahaan secara signifikan pada tiga tahun belakangan ini.

Selain faktor tersebut di atas, XYZ saat ini juga terpengaruh terhadap ketidakpastian implementasi hukum sebagai dampak dari otonomi daerah di Indonesia. Seperti tumpang tindih lahan kuasa penambangan, tata guna lahan, dan proses perijinan. Selain itu terdapat peningkatan tuntutan Corporate Social Responsibility (CSR) sehubungan dengan kondisi sosialekonomi masyarakat di sekitar wilayah pertambangan yang masih rendah.

Pemetaan faktor-faktor di atas memaksa XYZ melaksanakan transformasi bisnis dengan mengeksekusi arahan strategi untuk mencapai visi perusahaan 2020. Melaksanakan transformasi bisnis dengan salah satunya adalah mengembangkan budaya perusahaan yang berkinerja tinggi seperti yang tercantum pada salah satu misi

Namun, pada saat ini XYZ belum mempunyai pemetaan dan konsep yang jelas mengenai pengembangan budaya organisasi yang komprehensif. Nilai-nilai perusahaan pun saat ini masih hanya bersifat pernyataan resmi perusahaan tetapi belum diselaraskan dengan komponen-komponen organisasi lainnya.

Salah satu komponen organisasi yang berhubungan dengan budaya organisasi adalah faktor kepemimpinan terutama bagi direksi dan eksekutif di XYZ. Drennan (1992) menyatakan bahwa pemimpin merupakan salah satu sumber utama budaya perusahaan. Di sisi lain, Rath dan Conchie (2008) mengungkapkan dari penelitian Gallup bahwa pemimpin yang efektif adalah mereka yang selalu berinvestasi terhadap "kekuatan" terutama pada aspek pengembangan bakat.

Sehubungan dengan penjelasan di atas, maka XYZ perlu mendesain pengembangan budaya organisasi serta mengelola perubahannya. Pengembangan budaya organisasi juga perlu mempertimbangkan salah satunya adalah bakat pimpinan XYZ yang mempunyai pengaruh dominan terhadap efektivitas pembentukan budaya organisasi. Diharapkan pengembangan budaya organisasi ini dapat merupakan sebagai salah satu upaya strategis untuk mencapai visi perusahaan 2020.

\subsection{Rumusan Masalah}

Sesuai dengan penjelasan latar belakang masalah di atas, maka masalah penelitian ini dapat dirumuskan sebagai berikut:

1. Bagaimana profil budaya $X Y Z$ saat ini, budaya yang diinginkan di masa depan serta budaya yang seharusnya di masa depan? 
2. Bagaimana dampak hasil pemetaan bakat para eksekutif di XYZ terhadap profil budaya yang seharus di masa depan yang selaras dengan visi perusahaan?

3. Bagaimana proses pengembangan budaya untuk mengaktualisasikan nilainilai perusahaan serta mencapai profil budaya yang seharusnya di masa depan?

\subsection{Tujuan Penulisan} berikut:

Tujuan penelitian ini adalah sebagai

1. Teridentifikasinya profil budaya perusahaan saat ini.

2. Teridentifikasinya profil budaya yang diinginkan dan profil budaya yang seharusnya sesuai dengan visi dan misi perusahaan.

3. Teridentifikasinya kesesuaian profil budaya yang seharusnya dengan nilainilai perusahaan yang baru dan bakat para eksekutif di XYZ.

4. Tersedianya rancangan pengembangan budaya organisasi yang selaras dengan visi dan misi perusahaan.

\section{TINJAUAN PUSTAKA}

\subsection{Budaya Organisasi}

Schein (2004) mendefenisikan

budaya adalah suatu pola asumsi dasar yang diciptakan, ditemukan atau dikembangkan oleh kelompok tertentu sebagai pembelajaran untuk mengatasi masalah adaptasi eksternal dan integrasi internal yang resmi dan terlaksana dengan baik dan oleh karena itu diajarkan dan diwariskan kepada anggotaanggota baru sebagai cara yang tepat memahami, memikirkan, dan merasakan terkait masalah-masalah tertentu (hal.17). Robbins (2007) mendefenisikan budaya organisasi adalah sistem nilai yang disebarkan oleh anggota-anggota organisasi yang akan membedakannya dengan organisasi lainnya (hal. 511). Jadi dalam studi ini, budaya organisasi dimaknakan sebagai suatu pola nilai dan asumsi yang membedakan suatu organisasi dengan organisasi lainnya.

Untuk dapat lebih memahami defenisi budaya organisasi, maka Schein (2004) membagi level budaya organisasi tiga bagian sebagai berikut:

\section{Artifak}

Artifak mencakup semua fenomena yang bisa dilihat, didengar, dan dirasakan.

2. Kepercayaan dan Nilai

Nilai-nilai adalah filosofi, sasaran dan solusi yang muncul dari orang-orang dalam organisasi dengan maksud memecahkan masalah-masalah dalam organisasi tersebut.

3. Asumsi Dasar

Dalam asumsi dasar terdapat petunjukpetunjuk yang harus dipenuhi oleh organisasi menyangkut perilaku nyata, termasuk menjelaskan anggota kelompok bagaimana merasakan, memikirkan segala sesuatu.

Kotter dan Heskett (1992 dalam Tika, 2006) mengungkapkan bahwa budaya perusahaan dapat mempunyai dampak yang berarti terhadap kinerja ekonomi jangka panjang.. Budaya yang kuat berkaitan dengan kinerja yang unggul melalui penyatuan tujuan, menciptakan motivasi yang luar biasa dalam diri pegawai dan memberikan struktur dan kontrol yang dibutuhkan tanpa harus bersandar pada birokrasi formal.

\subsection{Organizational Culture Assessment Instrument (OCAI)}

Budaya organisasi merupakan sesuatu yang abstrak. Menurut Schein (2004) bahwa secara umum budaya organisasi yang abstrak tersebut dapat digambarkan dalam bentuk suatu kategori tertentu. Penggambaran budaya organisasi ke dalam bentuk kategori akan mempermudah 
menganalisis variasi budaya organisasi yang akan dianalisis

Cameron and Quinn (2006) menjelaskan bahwa Organizational Culture Assessment Instrument (OCAI) ini berdasarkan model teori yang dikenal sebagai Competing Value Framework (CVF). Konsep ini dipandang sangat ampuh untuk menjelaskan berbagai fenomena organisasi. OCAI mampu menjelaskan profil budaya organisasi secara komprehensif baik untuk profil budaya saat ini maupun profil budaya di masa mendatang. Hal ini disebabkan kerena OCAI meliputi dimensidimensi sebagai berikut:

1. Karakteristik organisasi yang Dominan

2. Gaya kepemimpinan dan pendekatan keseluruh bagian organisasi

3. Pengelolaan pegawai dan karakteristik bagaimana memperlakukan pegawai serta bagaimana lingkungan kerja yang diinginkan.
4. Pengikat organisasi atau mekanisme yang menjaga keutuhan organisasi

5. Penekanan terhadap strategi

6. Kriteria Kesuksesan

CVF terdiri dari dua dimensi. Dimensi pertama mendiferensiasi kriteria efektif yang menekankan pada keluwesan, diskresi, dan dinamis, dibandingkan dengan kriteria yang menekankan pada kestabilan, ketataurutan, dan pengendalian. Dimensi kedua mendiferensiasi kriteria efektif yang menekankan pada orientasi pada lingkungan internal perusahaan, integrasi, dan kesatuan, dibandingkan dengan kriteria efektif yang menekankan pada orientasi pada lingkungan ekternal perusahaan, keunikan atau inovasi, dan persaingan. Seperti ditunjukkan pada Gambar 1., kedua dimensi secara bersamasama akan memberikan empat alternatif budaya organisasi yaitu hierarchy, clan, adhocracy, dan market.

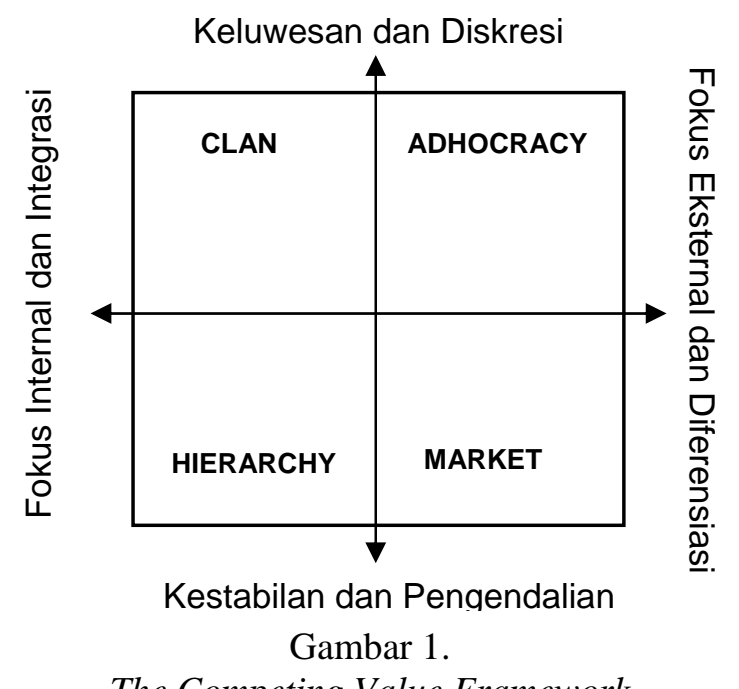

The Competing Value Framework

1. Budaya Hierarki (The Hierarchy pengendalian, serta mekanisme Culture) akuntabilitas dinilai dan dihargai sebagai Garis wewenang (authority) pengambilan keputusan yang jelas, kunci untuk sukses. 
2. Budaya Pasar (The Market Culture) Jenis organisasi ini lebih berorientasi pada kinerja. Fokus utamanya adalah bagaimana dapat menyelesaikan pekerjaan secara cepat. Orang-orang dalam organisasi sangat kompetitif dan berorientasi pada kinerja.

3. Budaya Keluarga Besar (The Clan Culture)

Disebut Clan atau keluarga besar karena jenis organisasinya mirip dengan organisasi keluarga. Nilai dan tujuan yang dibagi bersama, kesatupaduan, kepribadian, partisipasi, dan rasa kebersamaan yang diserap merupakan indikator perusahaan dengan budaya kekeluargaan..

4. Budaya Adhokrasi (The Adhocracy Culture)

Akar kata dari adhokrasi adalah ad hoc: menunjukan sesuatu yang bersifat sementara, spesialisasi, unit yang dinamis. Asumsinya adalah bahwa sifat inovatif dan tindakan untuk memelopori inisiatif adalah penyebab organisasi ini sukses, terutama dalam bisnis pengembangan produk dan jasa baru serta penyiapan untuk masa depan.

\subsection{Budaya dan Kepemimpinan}

Schein (2004) menyatakan bahwa budaya dan kepemimpinan itu dapat diibaratkan dua sisi pada suatu koin. Kepemimpinan adalah sumber dari kepercayaan dan nilai yang akan membawa organisasi berhubungan dengan masalah internal dan eksternal. Pada posisi ini isu yang paling penting bagi para pemimpin adalah bagaimana melaksanakan level yang paling dalam dari budaya serta bagaimana mengelola kegelisahan organisasi ketika terdapat tantangan bisnis yang tidak sesuai dengan level terdalam tersebut.

Namun, di sisi lain nilai-nilai yang ada di organisasi menjadi salah satu faktor penentu penting untuk memilih para pemimpin pada semua level. Hal ini disebabkan oleh salah satu peran utama pemimpin adalah menciptakan dan mengelola budaya yang kuat dan adaptif.

Bakat kepemimpinan sangat dominan pengaruhnya terhadap masingmasing profil budaya organisasi yang ingin dicapai. Hal ini disebabkan profil budaya organisasi yang berbeda menuntut peran dominan pemimpin yang berbeda pula. Seperti yang terlihat pada Gambar 2., Cameron and Schein (2006) menyatakan bahwa terdapat tipe dominan pemimpin yang berbeda untuk masing-masing tipe budaya organisasi. 


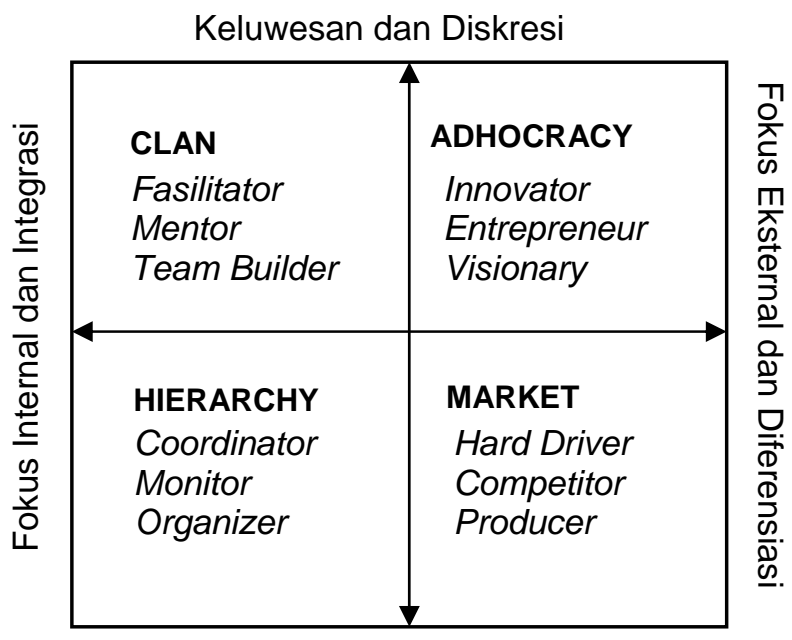

Kestabilan dan Pengendalian

Gambar 2.

Tipe Pemimpin sesuai dengan Tipe Budaya

\subsection{Pengelolaan Perubahan Budaya budaya organisasi nantinya benar-benar Organisasi \\ Scheiner dan Betty (1994, dalam dapat membawa perubahan perilaku kerja individu didalam organisasi. Pada Gambar 3. Soetjipto 2007) mengungkapkan bahwa manajemen perlu memastikan adaptasi ditunjukkan tiga elemen pokok implementasi perubahan budaya.} budaya berjalan efektif agar perubahan

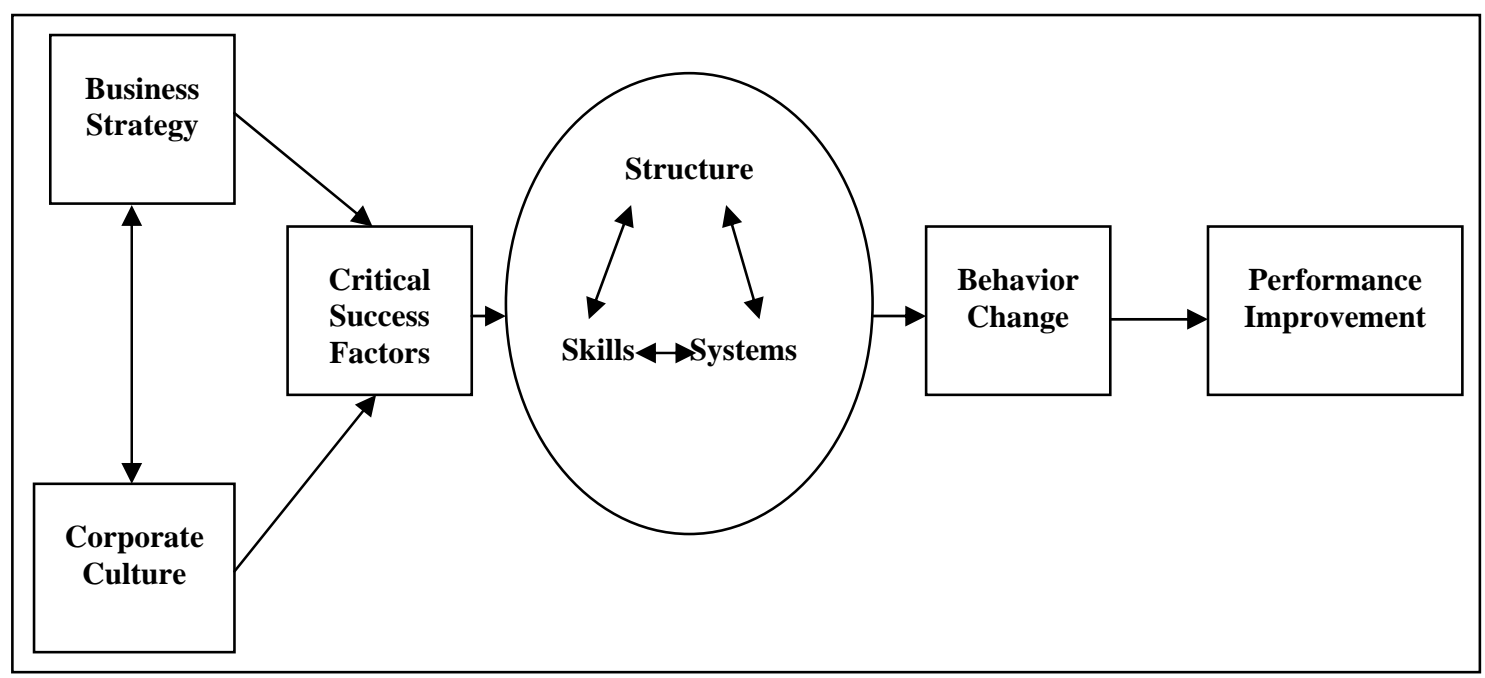

Gambar 3.

Model Perubahan Budaya 
Sejalan dengan model yang dikembangkan Schneier dan Beatty (1994) untuk perubahan budaya, perusahaan konsultan Booz Allen Hamillton (2004) juga mengembangkan model untuk bagaimana menyelaraskan organisasi dengan nilai-nilai yang baru. Elemen-elemen dari model tersebut dapat diuraikan sebagai berikut:

1. Penyelarasan peran Kepemimpinan

Aktualisasi nilai-nilai perusahaan yang baru dimulai dari manajemen puncak dan diturunkan keseluruh organisasi.

2. Komunikasi yang konsisten

Penyebarluasan

nilai-nilai

perusahaan yang baru keseluruh lapisan organisasi serta mengajak kelompokkelompok karyawan untuk mengeksplorasi dan mengetahui kenapa harus berubah dan arah perubahan yang diharapkan, serta peran aktif dari pegawai dalam mengaktualisasikan nilainilai perusahaan.

3. Peningkatan kapabilitas pegawai
Menghidupkan nilai-nilai perusahaan yang baru artinya yaitu menanamkan keahlian-keahlian yang dibutuhkan dalam diri karyawan-karyawannya untuk dapat meninggalkan cara-cara lama dalam melakukan pekerjaan.

4. Pengoptimalan sistem dan prosedur Sistem dan aturan-aturan di perusahaan harus menunjang transformasi menuju nilai-nilai perusahaan yang baru.

\section{KERANGKA ANALISIS}

Pada Gambar 4. dapat ditunjukkan desain kerangka analisis pada penelitian ini. Pembahasan penelitian ini dimulai dengan melaksanaan analisis level budaya yang meliputi artifak, nilai dan kepercayaan serta asumsi dasar. Analisis budaya dilanjutkan dengan pemetaan profil budaya yang sedang berlangsung saat ini. Pada saat yang bersamaan dilakukan juga pemetaan profil budaya XYZ yang diinginkan di masa depan.

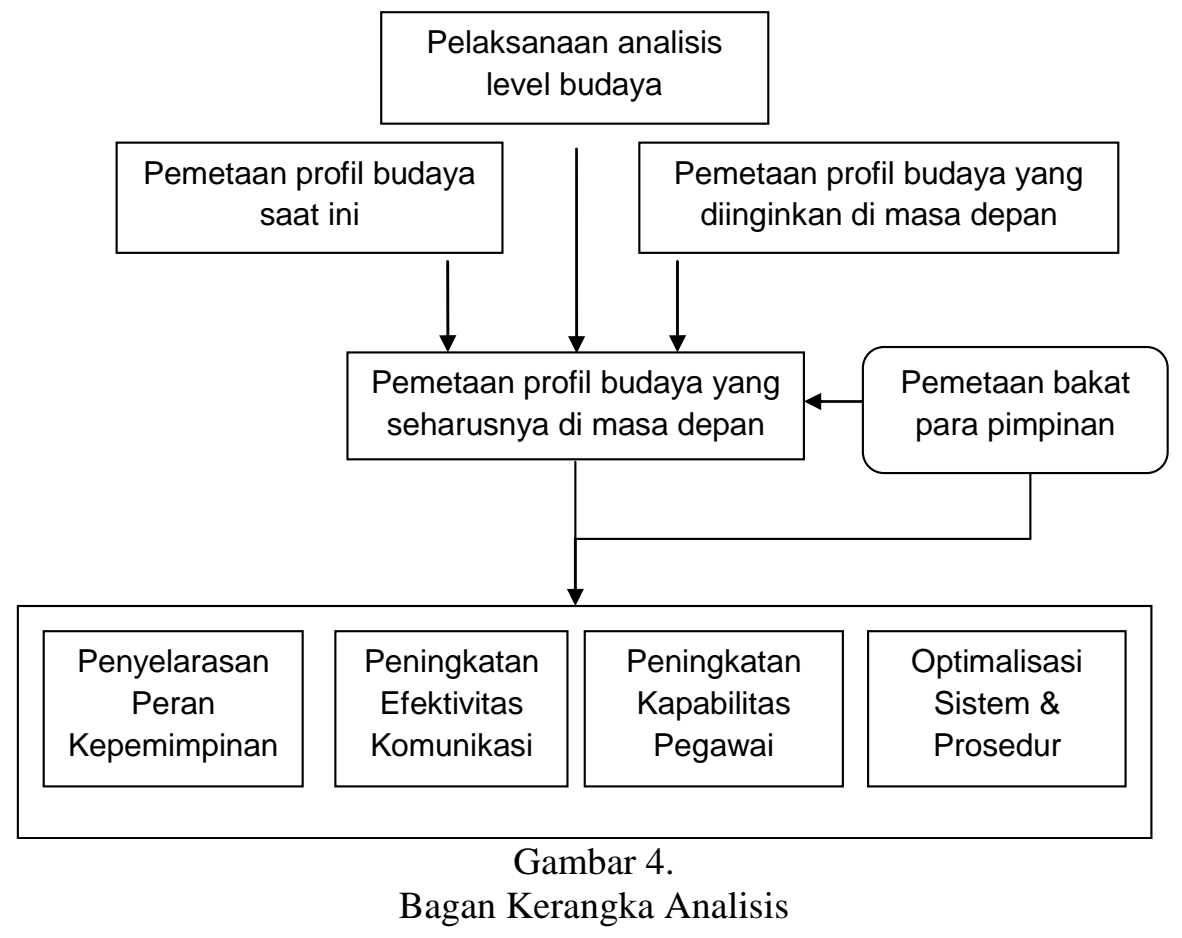


Pemetaan profil budaya masa depan difokuskan pada tahun 2020 karena diselaraskan dengan pemenuhan terhadap nilai-nilai perusahaan yang baru serta visi dan misi perusahaan 2020.

Pemetaan profil budaya saat ini dan profil budaya di masa datang dilakukan melalui OCAI yang terdiri dari enam item. Masing-masing item terdiri dari empat alternatif pernyataan yang harus hasil penjumlahannya untuk masing-masing item adalah 100. Perbedaan antara profil budaya saat ini dan profil budaya masa depan kemudian dianalisis perbedaannya (discrepancy) dari sisi kekuatan dan kecenderungannya.

Selanjutnya harus dilaksanakan pemetaan profil budaya organisasi yang seharusnya di masa depan berdasarkan arahan strategi perusahaan. Pada tahapan ini juga dilakukan analisis kesenjangan antara hasil analisis level budaya dan profil budaya saat ini dengan profil budaya di masa depan.

Bakat para pimpinan (level eksekutif) perlu dianalisis kesesuaiannya dengan profil budaya seharusnya di masa depan. 34 bakat yang dikemukakan oleh Gallup akan dikelompokkan berdasarkan empat dimensi budaya yang berbeda. Pengelompokkan tersebut dilaksanakan berdasarkan tahapan sebagai berikut:

1. Identifikasi setiap tipe pemimpin yang sesuai dengan masing-masing dimensi budaya, yaitu clan, adhocrasy, market dan Hierarchy.

2. Identifikasi tujuh bakat dominan para pimpinan berdasarkan hasil talent mapping yang telah dilaksanakan di XYZ.

3. Bakat dominan tersebut akan disesuaikan dengan dimensi budaya yang sesuai yang telah dikelompokkan.

Hasil akhirnya adalah akan terlihat penyebaran (distribusi) bakat dominan para pimpinan berdasarkan dimensi budaya. Analisis bakat dominan para pemimpin yang disesuaikan dengan dimensi budaya ini penting untuk mengetahui seberapa besar usaha yang diperlukan dalam implementasi intervensi perubahan budaya organisasi.

Langkah selanjutnya adalah mengidentifikasikan intervensi-intervensi perubahan budaya organisasi yang mengarah kepada profil budaya yang seharusnya, nilainilai organisasi yang baru serta kesesuaiannya dengan bakat para pemimpin di perusahaan. Aspek-aspek intervensi tersebut adalah (sesuai dengan Scheiner dan Betty, 1994; dan Booz Allen Hamilton, 2004) pendekatan penyelarasan peran kepemimpinan, peningkatan efektivitas komunikasi, peningkatan kapabilitas pegawai serta optimalisasi sistem dan peraturan yang ada.

Penyelarasan peran kepemimpinan meliputi peran kepemimpinan dalam mengelola perubahan dan mendefinisikan atribut kepemimpinan XYZ yang selaras dengan profil budaya yang seharusnya. Peningkatan efektivitas komunikasi meliputi pedoman dan tahapan komunikasi komunikasi perubahan budaya. Peningkatan kapabilitas pegawai meliputi pengelolaan pelatihan pegawai, program pengembangan kepemimpinan serta inisiasi terhadap pengelolaan pengetahuan. Optimalisasi sistem dan prosedur meliputi sistem seleksi pegawai, sistem suksesi kepemimpinan, manajemen kinerja dan remunerasi serta rekrutmen dan seleksi.

\section{METODOLOGI}

\subsection{Tipe Penelitian}

Jenis Penelitian termasuk ke dalam penelitian terapan yang deskriptif. Penelitian deskriptif ini untuk mendapatkan profil budaya masa depan (diinginkan) dan 
dibandingkan dengan profil budaya saat ini. Hal yang paling penting pada penelitian ini adalah tindak lanjut dari hasil pemetaan profil budaya tersebut.

\subsection{Metode Pengumpulan Data}

Untuk mendapatkan data dan informasi yang sesuai, maka cara pengumpulan data pada penelitian ini adalah sebagai berikut:

a. Kuesioner

Pegawai (responden) diberikan suatu daftar pertanyaan mengenai profil budaya organisasi, dan pegawai tersebut dipersilakan untuk menjawab sendiri.

b. Wawancara

Wawancara digunakan untuk penggalian lebih mendalam mengenai profil budaya organisasi saat ini dan profil budaya masa depan dengan pimpinan perusahaan termasuk dengan Direksi. Wawancara juga digunakan untuk menggali intervensi pengembangan budaya dengan para Subject Matter Experts (SME) baik di internal maupun eksternal perusahaan.

c. Focus Group Discussion (FGD)
FGD ini digunakan untuk mengevaluasi hasil survei profil budaya organisasi serta pemetaan bakat pimpinan di perusahaan.

d. Studi Pustaka

Studi pustaka digunakan untuk mengumpulkan bahan-bahan yang berhubungan dengan pengembangan budaya organisasi yang berasal dari internal maupun dari eksternal organisasi.

\subsection{Populasi dan Sampel}

Populasi terdiri dari pegawai yang dianggap telah memahami arahan strategi perusahaan serta memahami nilai-nilai perusahaan yang baru. Berhubung hal tersebut, maka populasi dari penelitian deskriptif ini tidak melingkupi kategori jabatan pelaksana yang selama ini belum dilaksanakan sosialisasi terhadap arahan strategi dan nilai-nilai perusahaan yang baru.

Metode sampling yang digunakan adalah sampling acak tak proporsional menurut stratifikasi seperti yang terlihat pada Tabel 1.

Tabel 1.

Sampel Penelitian

\begin{tabular}{|c|c|c|c|c|c|}
\hline \multirow{3}{*}{ Unit Kerja } & \multicolumn{4}{|c|}{ Kategori Jabatan } & \multirow{2}{*}{ Total } \\
\cline { 2 - 5 } & Pelaksana & $\begin{array}{c}\text { Manajer Muda/ } \\
\text { Spesialis }\end{array}$ & $\begin{array}{c}\text { Manajer Utama / } \\
\text { Spesialis Utama }\end{array}$ & Eksekutif & \\
\hline Unit A & & 19 & 8 & 3 & 30 \\
\hline Unit B & & 5 & 3 & 2 & 9 \\
\hline Unit C & & 9 & 4 & 2 & 15 \\
\hline Unit D & & 5 & 2 & 1 & 8 \\
\hline Unit E & & 8 & 2 & 1 & 10 \\
\hline Unit F & & 2 & 2 & 1 & 4 \\
\hline Unit G & & 15 & 16 & 12 & 43 \\
\hline Total & & 63 & 36 & 21 & 119 \\
\hline
\end{tabular}




\subsection{Pengolahan Data}

Secara garis besar, langkah-langkah pengolahan data dilakukan sebagai berikut:

a. Editing

Editing pada penelitian ini lebih terhadap kelengkapan data, apakah pertanyaan yang diajukan kepada responden telah lengkap jawabannnya atau belum (data primer), apakah data sekunder yang diperlukan telah diperoleh atau belum.

b. Koding

Beberapa kriteria penting adalah berdasarkan unit kerja dan kategori jabatan yang ada.

c. Pengolahan Data Mentah

Pengolahan data bisa dilakukan dengan Microsoft Excel dengan komputasi yang sederhana.

\subsection{Pengujian Validitas dan Realibilitas}

a. Uji Validitas

Langkah-langkah mengukur validitas dapat dijelaskan sebagai berikut:

1) Melakukan uji coba kuesioner (kuesiner Bahasa Inggris versus kuesiner Bahasa Indonesia) pada sejumlah responden yang diambil berjumlah 10 orang. Kuesioner Berbahasa Inggris diberikan kepada responden satu minggu setelah mengembalikan Kuesioner Berbahasa Indonesia.

2) Menghitung nilai kuesiner tersebut dan melihat hasil kemiripan dari profil yang dihasilkan antara kuesioner Bahasa Indonesia dan kuesioner Bahasa Inggris.

3) Memperbaiki pernyataan pada kuesioner yang menggunakan Bahasa Indonesia apabila terdapat pernyataan yang tidak valid, kemudian melakukan langkah-langkah pengujian validitas dari awal kembali.

b. Uji Reliabilitas
Uji reliabilitas pada penelitian ini dilaksanakan dengan teknik test-retest dengan meminta responden yang sama untuk menjawab semua pertanyaan kuesioner sebanyak dua kali. Metode pengukuran reliabilitas sama dengan metode validitas yang telah dijelaskan di awal.

\section{ANALISIS PROFIL BUDAYA XYZ DAN MANAJEMEN PERUBAHANNYA}

\subsection{Identifikasi Level Budaya Saat ini 5.1.1 Artifak}

Dari proses pembentukannya dapat ditemukan bahwa XYZ telah ada pembentukan nilai dan asumsi tertentu dalam waktu puluhan tahun yang berasal dari perusahaan dan proyek yang berbeda. Masuknya XYZ ke bursa saham menyebabkan beberapa pandangan perseroan mulai lebih berorientasi untuk meningkatkan nilai bagi pemegang saham yang ditempuh dengan cara menurunkan biaya mengiringi pertumbuhan usaha untuk menjadi perusahaan yang berkelanjutan.

Penulis berpendapat bahwa mulai terdapat perubahan paradigma sebagian pegawai XYZ, terutama dalam hal paradigma berpikir dan perubahan budaya dari budaya pegawai negeri menjadi budaya pegawai swasta. Wilayah operasi yang tersebar menyebabkan bisa munculnya subsub budaya tertentu di masing-masing wilayah. Hal ini tentunya dapat dipengaruhi oleh budaya lokal dan karakteristik bisnis yang ada. Perubahan logo mencerminkan adanya upaya untuk merubah citra perusahan yang mempunyai kemampuan yang handal dalam bisnis pertambangan.

Selain itu, perubahan logo juga mencerminkan bahwa perusahaan ingin melepaskan kesan masa lalu yang kaku dan diharapkan di masa depan XYZ dapat lebih 
dinamis dan mampu beradaptasi sesuai dengan tuntutan bisnis yang ada. Dari aspek tata kelola perusahaan, XYZ telah menunjukkan perubahan yang cukup signifikan dalam beberapa tahun belakangan ini. Direksi dan Komisaris sangat menekankan adanya kebijakan dan prosedur yang detail terhadap semua proses bisnis yang ada untuk memastikan operasional dapat berjalan efektif dan efisien serta hubungannya dengan pemenuhan terhadap peraturan perundangan yang berlaku.

\subsubsection{Kepercayaan dan Nilai}

Nilai-nilai dan kepercayaan dapat tercermin dari falsafah dan, standar perilaku, dan standar etika.

a. Nilai

Pada tahun 2009, Direksi bersama pimpinan XYZ menetapkan nilai-nilai perusahaan yang baru PIONEER yang sebelumnya adalah PIONIR. Nilai-nilai dasar XYZ yang dianut dan diwujudkan dalam praktek bisnis sehari-hari saat ini adalah nilai-nilai PIONEER yang dapat diuraikan sebagai berikut:

1) Professionalism;

2) Integrity;

3) GlObal mentality;

4) HarmoNy;

5) ExcEllence;

6) Reputation.

PIONEER ini sebenarnya tidak terlalu berbeda dengan PIONIR yang merupakan nilai-nilai perusahaan sebelumnya berlaku. Dari penjelasan di atas, maka terdapat beberapa nilai-nilai perusahaan baru yang dianggap penting yaitu Excellence dan Global Mentality. Hal ini menandakan bahwa pencapaian kinerja terbaik dan beradaptasi terhadap lingkungan global merupakan standar perilaku yang dipentingkan oleh oleh setiap individu di XYZ saat ini dan masa depan. b. Standar Etika

Beberapa hal yang cukup detail di atur dalam standar etika XYZ dibandingkan perusahaan lain adalah mengenai K3L dan kemitraan dengan masyarakat. Hal ini mengindikasikan bahwa XYZ sebagai perusahaan tambang harus mengutamakan K3L dan mampu memberdayakan masyarakat di sekitar wilayah operasi.

\subsubsection{Asumsi Dasar}

Insan XYZ masih meyakini bahwa kesuksesan perusahaan tidak hanya dapat dilihat dari rasio-rasio keuangan tetapi juga partisipasi XYZ dalam membantu pemerintah untuk melaksanakan pembangunan.

Direksi juga meyakini bahwa dalam menjalankan bisnis, XYZ wajib melaksanakan tata kelola perusahaan yang baik. Asumsi sebagai BUMN juga membawa dampak yang tidak baik. Proses pertumbuhan perusahaan yang agak lambat akibat sebagian keuntungan harus dialokasikan untuk kepentingan APBN. Selain itu pengelolaan perubahan (change management) membutuhkan waktu yang lama untuk menyesuaikan sistem dan prosedur selaras dengan tantangan bisnis yang ada.

\subsection{Analisis Profil Budaya Saat ini dan Masa Depan Dengan Metode OCAI}

Pada Gambar 5. diperlihatkan hasil pemetaan profil budaya organisasi XYZ. Profil budaya XYZ saat ini yang paling dominan adalah tipe Hierarki. Tipe Hierarki ini mencerminkan XYZ sebagai organisasi yang mempunyai peraturan dan prosedur standar, pengendalian serta mekanisme akuntabilitas didefenisikan secara jelas. Tipe budaya dominan kedua yaitu mencerminkan XYZ sebagai keluarga besar yang 
menunjukkan kerja tim, program keterlibatan pegawai, dan komitmen korporat kepada para pegawai. Selanjutnya bahwa tipe budaya dominan ketiga dan keempat adalah Pasar dan Adhokrasi.

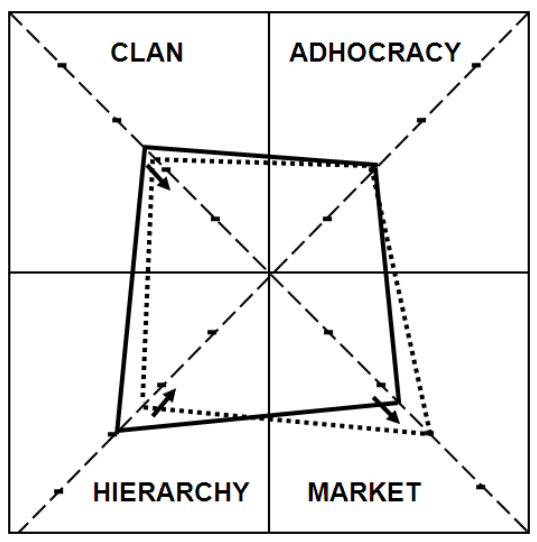

Gambar 5.

Profil Budaya Organisasi Keseluruhan XYZ

Profil budaya masa depan yang dominan sesuai persepsi responden adalah tipe Market. Tipe Market (pasar) ini mengharuskan XYZ untuk lebih berorientasi menuju lingkungan eksternal dari pada internal. Fokus utamanya adalah menciptakan keunggulan kompetitif melalui kompetisi dan produktifitas serta kinerja tinggi. Tipe budaya Hierarki merupakan tipe dominan kedua yang sebaiknya dipertahankan kerena masih dianggap perlu untuk fokus terhadap operasional yang berbiaya rendah. Tipe budaya yang dominan ketiga dan keempat di masa depan adalah Keluarga Besar dan Adhokrasi. Tipe budaya ini tidak berarti tidak penting menunjang pencapaian visi XYZ di masa depan tetapi dalam aspek-aspek tertentu tipe budaya ini sangat dibutuhkan. Hal ini ditandai dengan bobot untuk tipe budaya Keluarga Besar dan Adhokrasi masih berada di atas $20 \%$.

Dari hasil survey lainnya, ternyata profil budaya saat ini dan profil budaya masa depan XYZ yang paling dominan relatif sama untuk Unit Bisnis serta juga relatif sama dengan profil budaya organisasi keseluruhan XYZ. Untuk profil budaya saat ini masih didominasi oleh tipe Hierarki dan profil budaya masa depan masih didominasi tipe Pasar.

Hal yang sama juga dapat diamati bahwa profil budaya organisasi XYZ versi pimpinan yang sama dengan pola profil budaya organisasi keseluruhan XYZ. Namun, untuk profil budaya organisasi masa depan, tipe Pasar di versi pimpinan relatif lebih dominan dari pada versi keseluruhan di XYZ.

\subsection{Pemetaan Profil Budaya XYZ yang Seharusnya Di Masa Depan \\ 5.3.1 Visi dan Misi dan Strategi XYZ}

Penerjemahan Visi dan Misi dapat diungkapkan pada Rencana Jangka Panjang Perusahaan (RJPP) yang telah menetapkan tema strategi utama yaitu fokus terhadap proyek-proyek pengembangan dan aliansi strategis yang mempunyai nilai tambah yang tinggi. Tema strategi ini merupakan langkah awal sebagai terjemahan dari visi dan misi XYZ 2020 untuk menjadi perusahaan global dan mempunyai kinerja yang tinggi untuk 
memastikan pertumbuhan keberlanjutan perusahaan.

\subsubsection{Kriteria Efektivitas Organisasi}

Pencapaian hasil terhadap sasaransasaran sasaran kinerja dan peningkatan kapasitas pasar merupakan kriteria efektivitas organisasi yang penting saat ini dan masa depan. Selain itu, faktor kecepatan dalam mengeksekusi strategi terutama dalam melaksanakan insiatif pertumbuhan harus menjadi fokus utama dengan mengoptimalkan semua sumber daya yang ada.

\subsubsection{Nilai-nilai dan perilaku dominan}

Seperti yang telah dijelaskan pada nilai-nilai perusahaan bahwa beberapa nilai yang ditekankan saat ini dan masa depan adalah Excellence dan Global Mentality. Nilai Excellence ini mengharuskan pegawai
XYZ diantaranya adalah mempunyai mental pemenang, keyakinan kuat, dan sikap positif serta kerja keras untuk melakukan yang terbaik guna mencapai kinerja unggul. Sedangkan Global Mentality menuntut pegawai dapat beradaptasi terhadap lingkungan eksternal dan membangun mental global.

\subsection{Analisis Kesesuaian Bakat Eksekutif XYZ \\ Para pimpinan (eksekutif) XYZ telah} melaksanakan pemetaan bakat yang dapat mengungkapkan bakat dominannya masingmasing. Bakat dominan ini kemudian disesuaikan dengan profil budaya berdasarkan OCAI. Hasilnya adalah akan terlihat persebaran bakat dominan para pimpinan berdasarkan tipe budaya pada Gambar 6.

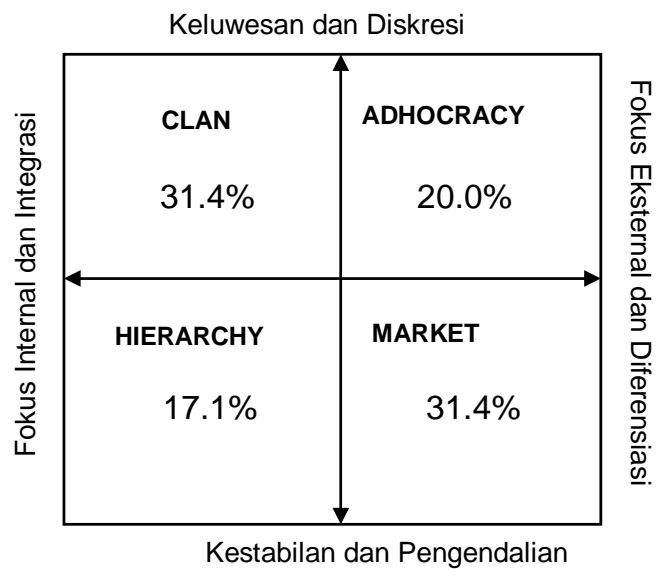

Gambar 6.

Persentase Populasi Bakat Eksekutif Terhadap Tipe Budaya

Gambar 6. menunjukkan persentase populasi bakat dominan eksekutif XYZ adalah tipe budaya Market dan Clan. Bakat Market dan Clan ini sangat dominan dibandingkan dengan tipe budaya Adhocracy dan Hierarchy. Bakat dominan ini secara umum selaras dengan profil budaya perusahaan yang seharusnya di masa depan. Profil budaya yang seharusnya di masa depan menuntut orang-orang XYZ mampu berkompetisi dan melakukan pekerjaan dengan cepat serta mampu menghasilkan kinerja yang unggul. Hal ini ditunjukkan oleh bakat dominan yang sesuai dengan tipe 
market diantaranya adalah Achiever, Maximizer dan Competition. Bakat eksekutif yang bertipe market ini diperkaya oleh bakat dominan eksekutif dengan tipe Clan yang bersifat Developer, Connectedness dan Positivity.

Hasil pemetaan profil budaya yang telah dilakukan di atas menunjukkan terdapat perbedaan profil budaya saat ini dengan profil budaya yang seharusnya di masa depan. Apabila dianalisis dari level budaya yang ada, maka proses perubahan budaya cukup sulit dilaksanakan apabila dianalisis dari level budaya yang ada. Saat ini belum muncul asumsi dasar yang mencirikan terhadap hasrat kuat individu di XYZ untuk dapat berkompetisi dan menghasilkan kinerja tinggi. Dari asumsi dasar yang ada saat ini juga dapat dikemukakan bahwa proses perubahan berjalan cukup lambat apalagi dikaitkan dengan perubahan perilaku.

Namun, persepsi pegawai mengenai profil budaya yang diinginkan di masa depan selaras dengan tipe budaya yang seharus di masa depan. Hal ini bisa mempermudah usaha dalam proses pengelolaan perubahan budaya XYZ untuk mencapai visi dan misi perusahaan. Apalagi terdapat kesesuaian bakat dominan sebagian eksekutif XYZ dengan tipe budaya seharusnya di masa depan yang akan mempercepat proses perubahan budaya.

\subsection{Pengelolaan Perubahan Budaya XYZ}

Pengelolaan perubahan budaya XYZ dilaksanakan berdasarkan hasil pemetaan profil budaya yang telah dilaksanakan. Perubahan budaya ini bukan sesuatu hal yang mudah untuk mengelolanya. Perubahan budaya hanya akan terjadi apabila berhasil merubah perilaku orang-orang yang ada, terdapat perubahan sistem kerja serta adanya pergeseran asumsi dasar yang dianut sebagian besar orang-orang di XYZ dalam jangka panjang.

Sehubungan dengan hal tersebut, perubahan budaya diawali dengan menerapkan insiatif-inisiatif perubahan yang mengarah kepada tipe budaya Market dan nilai-nilai perusahaan terutama yang berhubungan dengan nilai excellence. Insiatif-inisiatif perubahan meliputi aspekaspek penyelarasan peran kepemimpinan, peningkatan efektivitas komunikasi, peningkatan kapabilitas pegawai serta optimasi sistem dan prosedur yang terkait.

1. Penyelarasan Kepemimpinan

Peran kepemimpinan dari para Direksi XYZ memegang faktor kunci agar terlaksananya perubahan budaya yang lebih kompetitif dan berorientasi hasil. Hal ini disebabkan karena kepemimpinan adalah sumber dari kepercayaan dan nilai yang akan membawa organisasi dalam menghadapi tantangan bisnis. Beberapa peran kunci yang harus dilaksanakan oleh dari Direksi di XYZ adalah membangun sense of urgency dengan menetapkan standar kinerja yang menantang serta menerapkan penghargaan dan pemberdayaan berbasis kinerja. Visualisasi komitmen Direksi dan membangun tim perubahan budaya serta memfasilitasi perubahan budaya akan dapat mempercepat proses mencairkan situasi dan mempersiapkan proses perubahan. Penyelarasan peran kepemimpinan ini harus dilaksanakan di awal inisiatif-inisiatif perubahan budaya organisasi.

2. Peningkatan efektivitas Komunikasi

Dukungan hanya didapatkan apabila terdapat persamaan pemahaman dan persepsi oleh sebagian besar pegawai. Kesamaan pemahaman ini hanya akan terbentuk apabila terjadi komunikasi 
sehingga didapatkan komitmen oleh sebagian besar pegawai. Komunikasi perubahan budaya ini perlu dlaksanakan dengan dengan menggunakan bahasa yang sederhana disertai dengan serta contoh-contoh yang relevan, dilaksanakan secara berulang-ulang dan memanfaatkan berbagai saluran komunikasi.

Terdapat beberapa tahapan komunikasi yang perlu dilaksanakan yaitu sosialisasi yang bertujuan untuk meningkatkan kesadaran dan pemahaman pegawai mengenai alasan perubahan budaya organisasi, perilaku apa yang diharapkan serta partisipasi apa yang diharapkan dari pegawai. Secara jangka panjang, perusahan juga perlu melaksanakan proses internalisasi melalui pengotimalan peran atasan dan komunikasi non verbal.

3. Peningkatan Kapabilitas Pegawai

Pada tipe budaya market pegawai diharapkan dapat memiliki antusiasme untuk menghasilkan kinerja di atas ratarata dan bekerja keras untuk melebihi harapan pelanggan (internal dan eksternal). Sehubungan dengan hal tersebut, maka pegawai harus mendapatkan pelatihan yang tepat untuk mendukung kinerjanya saat ini. Secara jangka panjang manajemen perlu melaksanakan program pengembangan kepemimpinan untuk dapat memaksimalkan peran pemimpinpemimpin.

4. Optimalisasi Sistem dan Prosedur

Perubahan budaya dalam jangka panjang harus didukung oleh sistem dan prosedur yang mampu "memaksa" individuindividu di dalam perusahaan untuk mengaktualisasikan nilai-nilai yang mencerminkan budaya perusahaaan yang berkinerja tinggi. Sistem dan prosedur ini tentunya berhubungan dengan pengelolaan SDM yang ada di perusahaan mengingat perubahan di dominasi oleh aspek manusia.

Sistem Suksesi Kepemimpinan perlu dilakukan menempatkan suksesor kepemimpinan fokus pada keselarasan bakat yang dipunyai oleh suksesor. Sistem Manajemen Kinerja perlu dioptimalkan dengan terlebih dahulu adanya Buy in oleh Direksi dan para eksekutif di perusahaan serta dilaksanakan secara bertahap. Sistem penghargaan perlu dibedakan antara pegawai-pegawai yang mempunyai kinerja tinggi dengan yang rata-rata dengan pengoptimalkan penghargaan yang dalam bentuk intrinsik dan kesempatan mengembangkan bakat pribadi. Proses rekrutmen dan seleksi di XYZ tidak hanya harus mendapatkan kualifikasi yang sesuai tetapi juga harus mendapatkan kandidat-kandidat yang atribut perilakunya sesuai dengan tipe budaya market dan nilai-nilai PIONEER.

\section{KESIMPULAN DAN SARAN}

\subsection{Kesimpulan}

Berdasarkan penelitian yang telah dilaksanakan, maka terdapat kesimpulan dalam hasil dan pengelolaan perubahan budaya organisasi sebagai berikut:

1. Pemetaan budaya dari aspek level budaya menunjukkan bahwa XYZ masih merupakan perusahaan yang menunjukkan paradigma seperti yang ditampilkan oleh BUMN pada umumnya. Namun, dari artifak dan pernyataan nilai-nilai perusahaan telah menunjukkan pergeseran paradigma untuk menjadi organisasi bisnis yang modern.

2. Hasil pemetaan profil budaya organisasi saat ini menunjukkan bahwa XYZ mempunyai tipe budaya hierarki. Tipe 
budaya ini mencerminkan XYZ sebagai organisasi yang mempunyai peraturan dan prosedur standar, pengendalian serta mekanisme akuntabilitas didefenisikan secara jelas

3. Terdapat keselarasan profil budaya organisasi yang diinginkan dan budaya yang seharusnya di masa depan. Tipe budaya yang berorientasi terhadap market yang berorientasi untuk menciptakan keunggulan kompetitif melalui kompetisi dan produktifitas.

4. Proses pengelolaan perubahan profil budaya organisasi saat ini menuju profil budaya masa depan dilaksanakan melalui inisiatif penyelarasan kepemimpinan, peningkatan efektivitas komunikasi, peningkatan kemampuan pegawai serta optimasi sistem dan prosedur yang ada. Inisiatif-inisiatif ini perlu memfasilitasi bakat eksekutif XYZ yang berperan sebagai change agent utama.

\subsection{Saran}

Saran-saran dari hasil penelitian ini dapat diuraikan sebagai berikut:

1. Direksi dan para eksekutif di XYZ perlu mendapatkan materi khusus mengenai pengelolaan perubahan budaya untuk dapat memahami proses perubahan budaya serta peran penting mereka dalam mengaktualisasikan nilai-nilai yang mencerminkan budaya organisasi berkinerja tinggi

2. Dalam eksekusi inisiatif-inisiatif pengelolaan perubahan budaya, perlu dilengkapi dengan pendekatan Organizational Development yang lebih komprehensif untuk mengetahui progres detail mengenai perubahan perilaku pegawai

3. Pengelolaan perubahan budaya ini perlu dijadikan salah satu sasaran strategis utama pada level korporat

4. Inisiatif-inisiatif yang diusulkan pada penelitian ini perlu ditindaklanjuti lebih mendetailkan ke dalam rencana kerja Satuan Kerja terkait dan dilaksanakan secara sistematis dan menyeluruh

5. Manajemen perlu menempatkan orang yang tepat pada jabatan yang berhubungan dengan pengembangan budaya organisasi yang memahami betul aspek pengelolaan perubahan budaya dan people system. 


\section{DAFTAR PUSTAKA}

Ankrah, N.A and Langford, D.A. "Architects and contractors: a comparative study of organizational cultures”. Construction Management and Economics Journal: Taylor \& Francis Ltd (2005) :598600

Booz\& Co. (2004). Measuring and Analyzing Corporate Values During Major Transformations. http://www.booz.com/media/uploads/MeasuringandAnalyzing

Buckingham, Marcus and Clifton, O. Donald O. Now, Discover you strength. London: Simon \& Schuster, 2005.

Cameron, Kim S. and Robert E. Quinn. Diagnosing and Changing Organizational Culture: Based on the Competing Values Framework (Rev. edition). San Fransisco: John Wiley \& Sons, 2006.

Center for Organizational Culture \& Leadership Development (COCLD) \& Red Piramid. Corporate Culture: Challenge to Excellence. Jakarta: Elexmedia Komputindo, 2007.

Chatab, Nevizond. Diagnostic Management. Jakarta: Serambi Ilmu Semesta, 2007.

Corporate Secretary PT XYZ Tbk, Empat Dasawarsa PT XYZ Tbk; Memaknai Alam, Melintas Masa. 2008

Drennan, David. Transforming Company Culture. Berkshire: McGraw-Hill, 1992.

Dubrin.. Leadership. Boston: Houghton Mifflin, 2007.

Gray JH and Densten. "Toward an Integrative Model of Organization Culture and Knowledge Management.” International Journal of Organisational Behaviour, Volume 9(2) (2005): 594-603.

Kasali, Rhenald. Change. Jakarta: Gramedia Pustaka Utama, 2006.

------Re-Code Your Change DNA. Jakarta: Gramedia Pustaka Utama, 2007.

Kotter, P, John. Leading change. Boston : Harvard Business School Press, 1996.

Mead, Richard. Cross-Culture Management Communication. Chichester England: John Willey \& Sons, 1993.

Michels Ed, Jones and Axelrod Beth. The War for Talent. Boston: Harvard Business School Press, 2001.

Moeljono, Djokosantoso. Reinvasi BUMN. Jakarta: Elexmedia Komputindo, 2004.

Pabunda Tika, Mohammad. Budaya Organisasi dan Peningkatan Kinerja Perusahaan. Jakarta: Bumi Aksara, 2006.

Press Release PT XYZ Tbk. 30 Oktober 2009. Jakarta.

Rath, Tom. Strength Finder 2.0. New York: Gallup Press, 2007.

Rath, Tom and Conchie, Barry. Strengths Based Leadership. New York: Gallup Press, 2008.

Rencana Jangka Panjang Perusahaan PT XYZ Tbk 2010 - 2014. Jakarta, 2009.

Robbins S.P and Judge T.A. Organizational Behavioral. New Jersey: Pearson Prentice Hall, 2007.

Satriono, Teguh dan Andree. How to Measure 5 of Training Evaluation. Jakarta: Intellectual Capital Publishing, 2007.

Schein, Edgar H. Organizational Culture and Leadership (3 ${ }^{\text {rd }}$ edition). San Francisco: Jossey-Bass, 2004.

Sekaran, Uma. Research Methods for Business ( $4^{\text {th }}$ edition). San Fransisco: John Wiley \& Sons, 2003.

Sumarsono, Sonny. Metode Riset Sumber Daya Manusia. Yogyakarta: Graha Ilmu, 2004.

Takeuchi, Hirotaka and Nonaka, Ikujiro. Hitotsubashi on Knowledge Management. Singapore: John Wiley \& Sons ,2004.

The Jakarta Consulting Group. Corporate Culture \& Organization Culture. Jakarta : JCG, 2008.

Umar, Husein. Metode Riset Bisnis. Jakarta: Gramedia Pustaka Utama, 2002. 